Hanna Zhaldak

\title{
DETERMINATION OF FEATURES OF DEVELOPMENT OF MODERN THEORIES OF MANAGEMENT
}

The object of research is the processes of development of modern management theories. One of the next problematic aspects is the identification of the peculiarities of the development of modern management theory in the period of digitalization and pandemic, which means a significant impact on the economy.

In the process of work general scientific methods were used: induction and deduction, analysis and synthesis, comparison, systematization. The analysis of scientific approaches to the definition of management is carried out; the main essential features of modern enterprises and management theories, respectively, are determined. It is determined that the theory of management at the present level undergoes significant transformations. In modern theories more and more attention is paid to: the intangible component and the peculiarities of its management; there is an active transition to digital technologies and digitalization of business; there is a need to use new management methods; organizational structures and corporate cultures are changing. This in turn contributes to the purposeful formation and development of such institutions within the organization as:

- trust and creative atmosphere of productive group work;

- development of organizational ties within the organization and outside it;

- development of innovative ability of the company's staff;

- use of experience of other organizations.

Based on the analysis, the following features of modern management theories are identified:

- in modern theories more and more attention is paid to the intangible component and the peculiarities of its management;

- active transition to digital technologies and digitalization of business;

- change in the subject of work in most employees, in particular, the transition to advanced information and communication technologies;

- the need to use new management methods;

- transformation of organizational structures and corporate cultures. This provides the possibility of effective modern management by planning the activities of the firm in the short, medium and long term, as well as obtaining the maximum possible profit with minimal costs in a rapidly changing environment.

Keywords: management theories, digital technologies, intangible assets, corporate culture, Agile philosophy.

\section{Introduction}

Modern socio-economic conditions of development of the society, which is under the influence of a pandemic, demand gradual change of approaches to management. More and more leading companies are beginning to acquire the features of digitalization and globalization, are characterized by a high level of social activity, the spread of organizational innovation and more. In this regard, new problems have arisen related to the management of socio-economic systems at the macro-, meso- and micro-levels. In particular, the problems of flexibility and adaptation to constant changes in the environment; time constraints; competitiveness of the individual and organization; communications and business communication.

The definition of modern management features and their use in the management of companies are relevant and need further solution. It is necessary to integrate new approaches to management, in particular, to management, which is based on physiological and mental aspects of man, based on new practical and theoretical knowledge.

The evolution of management theories took place in accordance with economic, political, socio-cultural processes of each stage of development of society. Culturological factors had a significant influence on the formation of the main directions and concepts of management, as value orientations determined the main elements of management, and the dominant type of culture influenced organizational behavior, motivation theories, management decisions, communication system in management [1, 2].

Currently, one of the problem areas is to determine the features of modern management theories, patterns of their formation and development, taking into account modern conditions of digital transformation and digitalization of 
business. Thus, works [3-5] are devoted to certain aspects of digital business transformation.

Thus, the object of research is the processes of development of modern management theories. The aim of research is to determine the features of the development of management theories in modern conditions of digital transformation of business and pandemic.

\section{Methods of research}

During the work, general scientific and special research methods were used:

- analysis and synthesis - for preliminary analysis with the formation of the problem, the definition of goals; to study the features of modern management;

- analogies, system approach - to determine the struc-

tural links between the elements of development of modern enterprise management.

Modern scientific approaches significantly increase the pace and scope of new inventions, products and services. Therefore, the management of companies is gaining an increasing innovative component and focus on self-development. In today's economy, knowledge is becoming the dominant factor in achieving the company's socio-economic goals. Factors such as land, labor and capital, which are traditional, in the modern economy directly, depend on the effective use of knowledge [2-4].

The concept of «management» is quite broad and is studied by various sciences. Traditionally, the definition of «management» is associated with the terms «administration» and «cybernetics» [5]. Next, the issues of system approach to management, the concept of «system», «elements of the system», «management functions» are considered. Representatives of various sciences - philosophers, sociologists, psychologists, jurists, political scientists, economists and others - invest in this concept its specific meaning. The thesis is true that although the management process is largely universal in different areas and industries, it is subject to the same laws [6].

Management is a purposeful and constant process of influence of the subject of management on the object of management. The object of management is various phenomena and processes: man, team, social community, mechanisms, technological processes, devices.

Management as a process of influence of the subject on the object of management is inconceivable without a management system, which is usually understood as a mechanism that guarantees many interconnected elements that function harmoniously and purposefully [7, 8].

As a rule, most members of society are members of one or more organizations, i.e. organizational relations - a characteristic feature of human existence. People enter the organization in order to solve problems through management processes [9].

An organization is a conscious association of people, which is characterized by the principles of systemic, reasonable organization, structure and aims to achieve certain social goals and solve socially significant problems. Every organization has the management processes needed to achieve its goals and objectives.

Thus, the basic definitions of management, organizational relations and organization are considered. However, there are questions regarding the definition of current trends in the development of management theories, areas for solving urgent problems that exist in the transition to a new type of management.

\section{Research results and discussion}

Modern management is a holistic system that includes important laws and patterns of enterprise operation, as well as planning, organization, motivation and control. The task of modern management is the integration of all parties and aspects of the company to achieve a common goal. An important task of modern management is the effective planning of the firm in the short, medium and long term, to ensure that the company receives the maximum possible profit with minimal costs in a rapidly changing environment. Achieving success in the management of the company to some extent possible with highly qualified management of all aspects of the company [10]. The enterprise is a production-economic and socio-ecological purposeful system [11]. This definition of the object of control means that:

- enterprise management system has a multi-purpose nature;

- management goals have a different nature (production, economic, social, environmental and technical goals);

- result of the enterprise is the effects of different nature, which characterize the degree of achievement of goals; - in the management system it is necessary to constantly monitor the change of goals and adjust the focus of the object of management (strategy), which is especially important in conditions of instability of the external environment, when the goal is initially a landmark;

- errors in setting and forecasting goals inevitably lead to a violation of the parity of goals and unjustified expenditure of resources;

- enterprise development, as well as production, is an ongoing process and is carried out in the interests of achieving the whole set of goals [12]

Effective and adequate to modern conditions of operation of management companies is the «mechanism» through which the company operates, achieves its goals, develops and enhances its potential [3]. In this context, it is possible to identify the following main tasks that should cover modern management theories [4]: adaptive and situational management; robotics, automation and digitalization of production.

Overcoming the growing complexity of management, the constant growth of innovation and product diversity and increasing instability of the external environment lead to the adaptation of enterprise functions (research, production, marketing) [13].

In the modern practice of foreign companies there are two trends in the management process [14]:

1. Develop more complex and fast-acting management systems to ensure that the complexity and speed of decision-making match the complexity and speed of change.

2. Simplify the management system, reduce the period of long-term planning and even abandon planning in favor of intuition and experience.

Along with this, let's note that the choice of one of the above management trends depends on the industry orientation of the enterprise, its size and type of activity.

It is also worth paying attention to the following features of modern management theories:

1. In modern theories more and more attention is paid to the intangible component and the peculiarities of its management. At the beginning of the XXI century there was a new direction in management theories - knowledge management. It is a systematic process of identifying, using and transmitting information and knowledge that people 
can create, improve and apply [15, 16]. Intellectual work, special knowledge and communications increase the competitiveness of the organization, become the main factors of creating added value. Knowledge penetrates into all areas and all stages of the economic process, and it is difficult to separate them from a product or service. An increasing part of the managerial influence is directed to the intangible assets of enterprises, and management is becoming innovative in nature [17]. Promising in this context is the use of innovative resources for enterprise development, in particular social capital [7].

2. Active transition to digital technologies and digitalization of business. Use of big data, neurotechnologies, artificial intelligence, quantum technologies, components of robotics and sensors, etc. The characteristics of big data are $\langle 3 \mathrm{~V} »$ : volume, speed and variability. As an example, it is possibel to cite companies in Germany, where most companies focus on the use of the latest technologies, including IoT in the manufacturing industry; or the US Industrial Internet strategy, which involves the creation of a comprehensive solution that combines information and production processes. According to Kondratiev's theory of cycles, humanity is currently undergoing the 5 th cycle in its development (since 1981), associated with the active development and implementation in practice of electronics, robotics, computing, laser, telecommunications technology. However, already in the 2030s and 2050s, based on the NBIC convergence of nano-, bio-, information and cognitive technologies, the onset of the so-called technological singularity is predicted - an explosive increase in the speed of scientific and technological progress aimed at creating artificial intelligence and self-reproducing machines.

3. Changing the subject of work in most employees [16], in particular, it is worth noting the transition to advanced information and communication technologies. Information systems are becoming the most important component of the production apparatus of the enterprise. New information technologies create new opportunities for organizational networks, which take the division of labor to a new level, allowing to form product production chains and distribution networks. These new conditions require new management methods that can ensure the success of the enterprise. Methods and forms of management within certain networks have become the content of the so-called network management. In addition, a significant amount of information, its variability, as well as the impossibility of rapid and high-quality analysis, lead to the fact that the management of most modern companies are unable to operate with «paper» data on market conditions, competitors, technological innovations and more. The use of the latest generation of information technology, including software based on artificial intelligence, is one of the important and significant competitive advantages of any organization, regardless of industry and field of activity. An important advantage is also the acceleration of all processes, both management and production, which in turn significantly reduces the cycles of product creation and market entry, making high-risk investment decisions.

4. The need to use new management methods. According to the management practice of most leading enterprises, scientific and technological progress has significantly intensified in the last 50 years. If earlier discoveries in science were quite rare (5-6 discoveries per 100 years), now there is an avalanche process (up to 1000 discoveries per year). For this reason, outdated authoritarian methods of governance are ineffective. New discoveries usually occur in the production process and therefore in modern conditions, business must manage the state apparatus, not vice versa, because the speed of making adequate decisions in the face of fierce global competition decides a lot. As practical experience shows, in today's economy the most effective in terms of management processes of self-organization. The modern innovation model is based on the processes of openness, self-organization and nonlinear development, where preference is given to small and medium-sized highly dynamic innovative enterprises. According to statistics from recent years, small businesses make a significant contribution to the development of economic systems of countries that are world leaders [13-15]. For example, in the United States there are more than 17 million small businesses, which generate $60 \%$ of gross national product. More than $90-95 \%$ of non-agricultural industrial enterprises in the United States are small. The structure of the economic system in other leading countries is similar. For example, Germany, Indonesia, China, Japan have a share of small and medium-sized businesses in the national economy over $60 \%$. Along with this, success factors are the formation of a high-quality economy, a combination of intelligence and intuition, new knowledge and processes of self-organization. The importance of the creative component is becoming more and more apparent.

5. Transformation of organizational structures and corporate cultures. Ensuring a creative atmosphere is better manifested in those organizations that are set up for horizontal cooperation, rather than vertically oriented management (which, for example, is quite common in most enterprises in Ukraine). Self-organized mobile socio-economic systems are successful in the modern high-quality economy. The synergistic effect of the interaction of such systems is the most effective. According to the World Trade Organization (WTO) classification, in the countries of the European Union (EU) more than half of the workers work using non-standard forms of labor relations and designing nonstandard organizational structures. Only $25 \%$ of employees have signed permanent contracts with employers, $35 \%$ are self-employed, of which $13 \%$ are employed on temporary contracts, $12 \%$ are employed in the informal sector of the economy. The growth of non-standard employment in the $\mathrm{EU}$ is due to the processes of increasing competition, which forces to look for new ways to reduce costs, which include the use of flexible forms of employment.

In the context of the above, it becomes clear that qualitative changes must undergo a corporate culture of the enterprise. In order to meet modern trends, it is advisable to implement modern management technologies. In particular, such technologies include the Agile philosophy (which is based, on the one hand, on the principles of lean manufacturing, and on the other - on the principles used in software development). It is characterized by the smallest number of hierarchies and the ability to respond quickly to the challenges of a dynamically changing world. After the Agile Manifesto was formulated in 2001, the scope of this approach has expanded significantly: from software development to the creation of new products and services in all sectors of the economy. The basic principles of Agile [16]:

- people and their interaction are more important than processes and tools;

- working product is more important than comprehensive documentation; 
- cooperation with the customer is more important than agreeing on the terms of the contract;

- readiness for change is more important than passing the previous plan.

A significant difference between Agile and traditional approaches to project management is that it focuses primarily not on the project implementation process itself, but on creating an atmosphere of cooperation and effective communication between project team members.

\section{Conclusions}

The study identified the following features of modern management theories:

- in modern theories more and more attention is paid to the intangible component and the peculiarities of its management;

- active transition to digital technologies and digitalization of business;

- change in the subject of work in most employees, in particular, the transition to advanced information and communication technologies;

- the need to use new management methods;

- transformation of organizational structures and corporate cultures.

It is determined that the intensity and quality of the transition to new requirements significantly depends on the innovative susceptibility of the enterprise.

The results of research conducted in the work will be useful to managers of modern enterprises, and the systematic implementation of defined methods of project management (in particular, Agile) can significantly increase the effectiveness of research and innovation development.

\section{References}

1. Zakharchyn, H. M. (Ed.) (2011). Evoliutsiinyi rozvytok system menedzhmentu i orhanizatsiinoi kultury. Korporatyona kultura. Available at: http://nebotan.info/corporative/management.php

2. Obodkova, E. A. (2011). Sovremennaia situatsiia v teorii i praktike mirovogo menedzhmenta. Omskii nauchnii vestnik, 4, 140-143. Available at: https://cyberleninka.ru/article/n/sovremennayasituatsiya-v-teorii-i-praktike-mirovogo-menedzhmenta/viewer
3. Tkachuk, H. O. (2019). Tsyfrovi transformatsii: vzaiemozviazok iz systemoiu ekonomichnoi bezpeky pidpryiemstva. Ekonomika kharchovoi promyslovosti, 11 (4), 42-50.

4. Tapskott, D.; Pisareva, S. (Ed.) (1999). Elektronno-tsifrovoe obschestvo: pliusy i minusy setevogo intellekta. Kyiv: ITN Press; Moscow: Refl-buk, 403.

5. Mesenbourg, T. L. (2001). Measuring the Digital Economy. US Bureau of the Census, Suitland.

6. Amosov, A. A. (2011). Povyshenie proizvoditelnosti truda. Ekonomist, 1, 205

7. Bazarov, T. Iu. (2011). Upravlenie personalom razvivaiuscheisia organizatsii. Moscow: IPK GS, 334.

8. Napravleniia $i$ tendentsii razvitiia sovremennogo menedzhmenta. Available at: https://finances.social/menedjment_695/napravleniya-tendentsii-razvitiya-sovremennogo-41196.html

9. Zhaldak, G. P. (2014). Formation bases of socioeconomic mechanism of innovative development of industrial enterprises. Technology Audit and Production Reserves, 3 (3 (17)), 43-46. doi: http:// doi.org/10.15587/2312-8372.2014.25398

10. Filev, V. V. (2008). Upravlenie rostom proizvoditelnosti truda Ekonomist, 3, 2-12

11. Dusharina, E. Iu. (2020). Key elements of corporate culture Journal of Economics and Business, 3-1 (60), 64-67. doi: http:// doi.org/10.24411/2411-0450-2020-10169

12. Tsurri, O. G. (2016). Firmennii stil v sozdanii blagopriiatnogo imidzha kompanii. Almanakh teoreticheskikh i prikladnykh issledovanii reklamy, 1, 91-96.

13. Gridneva, E. A. (2007). Firmennii stil kak problema sovremennoi estetiki. Vestnik Nizhegorodskogo universiteta im. N. I. Lobachevskogo, 6, 288-292.

14. Skulmovskaia, L. G., Klimenko, A. A. (2009). Korporativnye tsennosti kak faktor razvitiia korporativnoi kultury. Vestnik Tiumenskogo gosudarstvennogo universiteta, 4, 101-105.

15. Shevchenko, I. L. (2016). Korporativnaia kultura kak mekhanizm korporativnogo upravleniia. Vestnik Iuzhno-Uralskogo gosudarstvennogo universiteta, 4 (10), 116-121.

16. Okatov, A. V., Solovev, D. A. (2017). Poniatie i vidy korporativnoi kultury. Vestnik Tambovskogo universiteta, 3 (11), 35-47.

17. Merzlov, I. (2018). Rol AGILE v protsesse prekhoda k Industrii 4.0. Razvitie menedzhmenta v Industrii 4.0: perekhod $k$ kiberfizicheskim organizatsiiam $i$ formirovanie ikh sistem upravleniia. Perm, 94-98. Available at: http://www.psu.ru/files/ docs/science/books/sborniki/razvitie-menedzhmenta-v-industrii-4.pdf

Hanna Zhaldak, PhD, Department of Management, National Technical University of Ukraine «Igor Sikorsky Kyiv Polytechnic Institute», Kyiv, Ukraine, e-mail: ann17@i.ua, ORCID: http://orcid.org/0000$0003-3421-3648$ 